\title{
Immunomodulatory Potential of Patchouli Alcohol Isolated from Pogostemon cablin (Blanco) Benth (Lamiaceae) in Mice
}

\author{
Jin Bin Liao ${ }^{1 \dagger}$, Dian Wei Wu ${ }^{1 \dagger}$, Shao Zhong Peng ${ }^{2}$, Jian Hui Xie ${ }^{1}$, Yu Cui Li ${ }^{1}$, Ji \\ Yan Su${ }^{1}$, Jian Nan $\mathrm{Chen}^{3^{*}}$ and $\mathrm{Zi}$ Ren Su${ }^{1^{*}}$ \\ ${ }^{1}$ School of Chinese Materia Medica, Guangzhou University of Chinese Medicine, Guangzhou 510006, ${ }^{2}$ Guangzhou Wanglaoji \\ Pharmaceutical Company Limited, Guangzhou 510450, ${ }^{3}$ Institute of Higher Education, Guangzhou University of Chinese \\ Medicine, Guangzhou 510405, Guangdong, PR China
}

${ }^{*}$ For correspondence: Email: suziren@gzucm.edu.cn, chenjiannan@gzucm.edu.cn; Tel: +86-20-39358517; Fax: +86-20-39358390

\begin{abstract}
Purpose: To isolate and purify patchouli alcohol (PA), a tricyclic sesquiterpene constituent of Pogostemon cablin, and investigate its immunomodulatory potential in Kunming mice.

Methods: PA was prepared from an ethanol aqueous extract of $P$. cablin by silica gel column chromatography, and further purified by crystallization using $n$-hexane. Purity was assessed by analytical gas chromatography (GC) and confirmation of chemical structure performed by Fourier transform infrared (FTIR), nuclear magnetic resonance (NMR) spectroscopy and mass spectrometry (MS). The effect of PA from Pogostemon cablin on immunological function was studied by macrophage phagocytosis, immune organ index, serum immunoglobulin level and delayed type hypersensitivity (DTH) in mice that were administered orally doses of 20,40 and $80 \mathrm{mg} / \mathrm{kg}$.

Results: The purity of PA was $99.3 \%$. The oral administration of PA (40, or $80 \mathrm{mg} / \mathrm{kg}$ body weight) significantly increased the phagocytic index $(p<0.05)$, compared with prednisone acetate (PR) group. Administration of PA (80 mg/kg) boosted the production of circulating serum IgM (0.081 \pm 0.010$)$ and $\lg G(1.296 \pm 0.120)$, while $\lg M$ and $\lg$ in $P R$ group was $0.069 \pm 0.011(p<0.01)$ and $1.180 \pm 0.070(p$ $<0.01)$ respectively. However, $P A(20 \mathrm{mg} / \mathrm{kg})$ treatment elicited significant decrease in DTH induced by 2, 4-dinitro-chlorobenzene $(D N C B)$ in mice $(1.03 \pm 0.40, p<0.05)$, in comparison to DNCB-induced group $(1.67 \pm 0.84 \mathrm{mg})$.

Conclusion: These results suggest that PA has significant immunomodulatory properties which probably act by activating mononuclear phagocytic system, augmenting humoral immune response while suppressing cellular immune response.
\end{abstract}

Keywords: Patchouli alcohol, Pogostemon cablin, Immunomodulatory, Phagocytic index, Macrophage

Tropical Journal of Pharmaceutical Research is indexed by Science Citation Index (SciSearch), Scopus, International Pharmaceutical Abstract, Chemical Abstracts, Embase, Index Copernicus, EBSCO, African Index Medicus, JournalSeek, Journal Citation Reports/Science Edition, Directory of Open Access Journals (DOAJ), African Journal Online, Bioline International, Open-J-Gate and Pharmacy Abstracts

\section{INTRODUCTION}

The immune system is involved in the etiology as well as pathophysiologic mechanisms of various diseases, and its role has become increasingly important in understanding mechanisms involved in disease prevention and treatment [1]. The immune system has connections with a number of organs and can directly or indirectly influence the actions of many other organs, including the brain [2]. Hence modulation of immune response to alleviate disease has been of interest for a long time [3]. Immunomodulation, either by stimulation or suppression, can aid in maintaining 
disease-free state [4]. In recent decades, modulation of immune response using medicinal plant products, as a possible therapeutic measure, has become a subject of active scientific investigations [5].

To date, some medicinal plants have been demonstrated to exert anti-inflammatory, antistress and anti-cancer effects by modulating immune functions [6]. Pogostemon cablin is the dried aerial part of Pogostemon cablin (Blanco) Benth. (Lamiaceae). It is one of the extensively applied herbal medicines that have time-honored application history in Traditional Chinese Medicine (TCM) and Ayurveda. In China, Pogostemon cablin has been used for centuries in decoctions with other drugs for treating cold, diarrhoea, dermatitis, headache, fever and stimulating appetite. Patchouli oil, the essential oil of $P$. cablin, also showed medicinal properties which include immunomodulatory, and antiallergic activities [7, 8]. Patchouli alcohol (PA), the tricyclic sesquiterpene (CAS Registry Number 5986-55-0), is a major active ingredient of $P$. cablin and typically represents $30 \%$ to 40 $\%$ of the total mass of dozens of compounds in patchouli oil [9]. Therefore, the PA content has been widely used as an indicator for the quality assessment of $P$. cablin and patchouli oil. PA has an oral $L_{50}$ value of $4693 \mathrm{mg} / \mathrm{kg}$ in mice [10]. It has some interesting pharmacological activities, such as anti-emetic, and anti-influenza virus potency $[11,12]$. Recent work has also demonstrated the effectiveness of PA as an antiinflammatory agent in vivo and in vitro [10,13].

In spite of the reputed effectiveness of $P$. cablin in various disorders, there has not been any reporting of immunomodulatory activity ascribed to its components so far. However, it is not clear whether its use in treating these diseases is due to its direct healing effect per se or due to some immunomodulation induced by its phytochemical constituents. In view of the fact that PA represents an essential active ingredient of $P$. cablin and patchouli oil, it is possible that its immunomodulatory capacity might constitute an important component of their varied therapeutic effects. The present study was therefore undertaken to evaluate PA for its possible immunomodulatory potential, with respect to macrophage phagocytosis, serum immunoglobulin level, immune organ index, as well as delayed-type hypersensitivity (DTH) induced by 2, 4-dinitro-chlorobenzene (DNCB) in mice.

\section{EXPERIMENTAL}

\section{Plant material}

The aerial parts of Pogostemon cablin (Blanco) Benth. were purchased from Guangzhou Zhixing Pharmaceutical Co., Ltd. The botanical origins of the materials were further authenticated morphologically by Prof. Lai Xiaoping at School of Chinese Materia Medica, Guangzhou University of Chinese Medicine. The documenting voucher specimen (no.080528) was deposited in the herbarium of School of Chinese Materia Medica, Guangzhou University of Chinese Medicine.

\section{Isolation and purification}

PA was isolated as previously described [13]. Briefly, Pogostemon cablin $(18 \mathrm{~kg}$ ) was refluxed with $95 \% \mathrm{v} / \mathrm{v}$ ethanol/aqueous $(40 \mathrm{~L} \times 2,60 \mathrm{~min}$ each time). The extract was evaporated under vacuum to obtain a residue $(381 \mathrm{~g})$. The residue was dissolved in acetone and subjected to column chromatography over silica gel, eluted with petroleum ether-ethyl acetate- $0.1 \%$ formic acid (20:1:0.1, 9:1:0.1, 8:3:0.1 and 7:4:0.1) gradient elution system in increasing polarity to give series of fractions. Thin layer chromatography was permitted to distinguish the resulting fractions and the fraction eluted with petroleum ether-ethyl acetate- $0.1 \%$ formic acid (9:1:0.1) was combined and further evaporated to dryness to yield yellowish oily liquid. After crystallization from n-hexane, white crystals of PA $(1.7925 \mathrm{~g}$, yield $0.011 \%)$ were finally obtained. The purity was assessed by analytical GC and the confirmation of chemical structure was performed by FTIR, MS and NMR spectroscopy.

\section{Purity determination}

Gas chromatographic analysis was performed on a model GC (Varian 3900, USA) equipped with a split/splitless capillary (1:20) injector and a flame ionization detector. Analytical separation was achieved on a 007-225 capillary column (30 m x $0.25 \mathrm{~mm} \times 0.25 \mu \mathrm{m}$, Phenomenex, USA). Nitrogen was used as carrier gas (with a constant flow rate of $1 \mathrm{ml} / \mathrm{min}$ ). The air, hydrogen and auxiliary gas $\left(\mathrm{N}_{2}\right)$ pressures for detector were kept 350,30 and $30 \mathrm{ml} / \mathrm{min}$, respectively. Temperature setting was as follows: injector, 280 ${ }^{\circ} \mathrm{C}$; detector, $280{ }^{\circ} \mathrm{C}$. The oven temperature was held at $110{ }^{\circ} \mathrm{C}$ for $7 \mathrm{~min}$, and programmed to 168 ${ }^{\circ} \mathrm{C}$ at $100{ }^{\circ} \mathrm{C}$ per min, held for $7 \mathrm{~min}$, and programmed to $190{ }^{\circ} \mathrm{C}$ at $40{ }^{\circ} \mathrm{C}$ per min, held for $2 \mathrm{~min}$, and programmed to $240{ }^{\circ} \mathrm{C}$ at $60^{\circ} \mathrm{C}$ per 
min, held for 2 min. $72 \mathrm{mg}$ of PA was dissolved in $10 \mathrm{ml}$ of $\mathrm{n}$-hexane, and the injection volume was $1 \mu \mathrm{L}$.

\section{Experimental animals}

Kunming mice, 4 - 5 weeks old and average weight $18 \pm 2 \mathrm{~g}$, were obtained from the Medical Experiment Animal Center of Guangzhou University of Chinese Medicine. All the experimental protocols and schedules involving animals were approved (ref. no. SYXK(YUE)2008-0085) by the Animal Welfare Committee of Guangzhou University of Chinese Medicine, and the Guidelines for Good Practice in Laboratory Animals Feeding and Management was followed [14]. During the experimental period, the mice were fed with standard rat chow and water ad libitum.

\section{Macrophage phagocytosis assay}

For assay of phagocytic activity in vivo a colloidal carbon clearance test was performed following the method of Hudson et al, with some modifications [15]. Mice of either sex were divided into six groups of 10 each, i.e., control group, prednisone acetate group (PR group), PAtreated groups $(20,40$ and $80 \mathrm{mg} / \mathrm{kg})$ and levamisole hydrochloride group (LE-treated group). They were pretreated with prednisone acetate (PR, $20 \mathrm{mg} / \mathrm{kg}$, p.o.) daily for 4 consecutive days prior to drug treatment except for the control group. PA-treated groups were administered PA at doses of 20,40 and 80 $\mathrm{mg} / \mathrm{kg}$, respectively, and LE-treated group was administered levamisole hydrochloride at a dose of $50 \mathrm{mg} / \mathrm{kg}$. PA-treated groups and LE-treated group were administered the respective doses via oral gavage once daily for 7 consecutive days from the $5^{\text {th }}$ day. Control group and PR group were given equivalent volume of olive oil throughout the experimental period. On the $11^{\text {th }}$ day, all animals were injected colloidal carbon ink intravenously $(1 \mathrm{ml} / 100 \mathrm{~g}) 1 \mathrm{~h}$ after the last administration. $2 \mathrm{~min}\left(\mathrm{t}_{1}\right)$ and $10 \mathrm{~min}\left(\mathrm{t}_{2}\right)$ after injection of carbon suspension, $20 \mu \mathrm{L}$ aliquots of blood samples were obtained from the retroorbital venous plexus of individual mice with a heparinized microhematocrit glass capillary, and immediately lysed with $3 \mathrm{ml} 0.1 \% \mathrm{Na}_{2} \mathrm{CO}_{3}$. The absorbances were measured spectrophotometrically at $680 \mathrm{~nm}$. The rate of carbon clearance, termed as phagocytic index $(K)$, was determined following the formula: $K=\left(\operatorname{InOD}_{1}-\right.$ InOD $) /\left(t_{2}-t_{1}\right)$, where $O D_{1}$ and $O_{2}$ are the optical densities at time $t_{1}$ and $t_{2}$ respectively.

\section{Humoral Immune Responses}

Humoral immune response assay was carried out according to the method of Duan et al, with some modifications [16]. Fresh blood was collected from white leghorn hens in sterile Alsever's solution (sodium citrate $0.8 \mathrm{~g} / \mathrm{ml}$, citric acid $0.05 \mathrm{~g} / \mathrm{ml}$, glucose $1.87 \mathrm{~g} / \mathrm{ml}$, sodium chloride $0.42 \mathrm{~g} / \mathrm{ml}$, freshly prepared). Chicken red blood cells (CRBC) were washed three times in pyrogen-free, sterile saline and centrifuged at $3000 \mathrm{rpm}$ for $10 \mathrm{~min}$. The supernatant was removed and the sediment was re-suspended in normal saline to a concentration of $5 \%$ by improved Neubaur chamber for immunization and challenge.

Mice of either sex were divided into six groups of 10 each, i.e. control group, prednisone acetate group (PR group), PA-treated groups (20, 40 and $80 \mathrm{mg} / \mathrm{kg}$ ) and levamisole hydrochloride group (LE-treated group). They were pretreated with prednisone acetate (PR, $20 \mathrm{mg} / \mathrm{kg}$, p.o.) daily for 4 consecutive days prior to drug treatment except for the control group. PA-treated groups were administered PA at the doses of 20, 40 and $80 \mathrm{mg} / \mathrm{kg}$, respectively, and LE-treated group was administered levamisole hydrochloride at the dose of $50 \mathrm{mg} / \mathrm{kg}$. PA-treated groups and LEtreated group were administered the respective doses via oral gavage once daily for 7 consecutive days from the $5^{\text {th }}$ day. Control group and PR group were given equivalent volume of olive oil throughout the experimental period. On the $9^{\text {th }}$ day, $1 \mathrm{~h}$ after administration, except the control group, mice were immunized with suspensions of CRBC, by intraperitoneal injection at a dose of $20 \mathrm{ml} / \mathrm{kg}$ body weight. On the $11^{\text {th }}$ day, $1 \mathrm{~h}$ after the final oral administration, all mice blood samples were collected from the retro-orbital venous plexus with heparinized microhematocrit glass capillary. After standing at room temperature for $30 \mathrm{~min}$, samples were centrifuged at $3000 \mathrm{rpm}$ for $10 \mathrm{~min}$ for serum preparation. For IgM assay, $10 \mu \mathrm{L}$ aliquots of above mentioned serum were diluted by normal saline to a final volume of $4 \mathrm{ml}$. Afterwards, $0.5 \mathrm{ml}$ of $5 \%$ CRBC, $0.5 \mathrm{ml} 10 \%$ guinea pig plasma and $0.5 \mathrm{ml}$ normal saline were added to $4 \mathrm{ml}$ diluted sera in sequence. For IgG assay, $10 \mu \mathrm{L}$ aliquots of serum was co-incubated with $10 \mu \mathrm{L} \beta$-mercaptoethanol at $37^{\circ} \mathrm{C}$ for $0.5 \mathrm{~h}$ to block IgM, and thereafter diluted by normal saline to a final volume of $4 \mathrm{ml}$. $0.5 \mathrm{ml}$ of $5 \%$ CRBC, $0.5 \mathrm{ml} 4 \%$ sheep anti-mouse (SAM) IgG and $0.5 \mathrm{ml} 10 \%$ guinea pig plasma were added to $4 \mathrm{ml}$ diluted sera in order. For control group, the complement was substituted with normal saline. The mixed samples for IgM assay and IgG assay were incubated for $30 \mathrm{~min}$ at $37^{\circ} \mathrm{C}$, 
and then immersed in an ice-water bath to terminate the reaction. Each sample was centrifuged at $3000 \mathrm{rpm}$ for $10 \mathrm{~min}$, and the absorbances of supernatant were measured by spectrophometry at $540 \mathrm{~nm}$ to represent the serum level of IgM and IgG. After blood sample collection, all the mice were sacrificed by cervical vertebrae dislocation and the immune organs including spleen and thymus gland were harvested and, weighed for calculation of immune organ indexes.

\section{DNCB-induced DTH}

Measurement of DNCB-induced DTH was carried out following the method of Ma et al, with slight modifications [17]. 60 Kunming mice of either sex were randomly assigned to five groups of 12 each. On the first day, mice were initially sensitized by applying $10 \mu \mathrm{L}$ of $5 \%$ DNCB in mixed acetone-olive oil $(4: 1, v / v)$ to the shaved abdomen skin and, the challenge was repeated through the same route the next day. After second sensitization, PA (20, 40 and $80 \mathrm{mg} / \mathrm{kg} / \mathrm{d}$, p.o.) and the reference drug prednisone acetate (PR, $40 \mathrm{mg} / \mathrm{kg} / \mathrm{d}, \quad$ p.o.) were administered respectively for 7 successive days from the third day, while DNCB-induced group was given equivalent volume of olive oil during this period. On the $9^{\text {th }}$ day, all mice were subjected to contact hypersensitivity with $10 \mu \mathrm{L}$ of $1 \%$ DNCB on both surfaces of left ear of mice, 40 min after the last dose. While the right ear was treated with olive oil alone. Twenty fours after the final DNCB application, all mice were sacrificed by cervical dislocation, and biopsy specimens of both ears were removed by a specific 8-mm punch. Ear swelling was evaluated by measuring the weight difference between the right and left ears, as an indicator of immunogen-elicited DTH.

\section{Statistical analysis}

The experiment was based on a completely randomized design. Data are presented as mean \pm SD for the indicated number of independently performed experiments. Statistical significances within a parameter were evaluated by one-way and multiple analysis of variation (ANOVA), where significant differences (as shown in the plots) indicated as * \# for $p<0.05$, and more significant **/ \#\# for $p<0.01$.

\section{RESULTS}

\section{Extraction and purification of PA}

PA: white crystals, $\mathrm{C}_{15} \mathrm{H}_{26} \mathrm{O}, \mathrm{Mp} 55.8^{\circ} \mathrm{C} .[\alpha]_{\mathrm{D}}^{25}=-$ 120 (c 2.0, $\mathrm{CHCl}_{3}$ ). IR (neat): $\mathrm{U}_{\max } / \mathrm{cm}^{-1}=3499$
(OH). ${ }^{1} \mathrm{H}$ NMR (300 MHz, $\left.\mathrm{CDCl}_{3}\right): \delta 1.85(3 \mathrm{H}, \mathrm{m})$, $1.68(1 \mathrm{H}, \mathrm{m}), 1.49(9 \mathrm{H}, \mathrm{m}), 1.17(1 \mathrm{H}, \mathrm{br} \mathrm{s}, \mathrm{OH})$, $1.06(3 \mathrm{H}, \mathrm{s}), 1.04(3 \mathrm{H}, \mathrm{s})$ and $0.83(3 \mathrm{H}, \mathrm{s}), 0.78$ $(3 \mathrm{H}, \mathrm{d}) .{ }^{13} \mathrm{C}$ NMR $\left(75 \mathrm{MHz}, \mathrm{CDCl}_{3}\right): \delta 76.0(\mathrm{C}, \mathrm{C}-$ $\mathrm{OH}), 44.0(\mathrm{CH}), 40.4(\mathrm{C}), 39.4(\mathrm{CH}), 38.0(\mathrm{C})$, $33.0\left(\mathrm{CH}_{2}\right), 29.2\left(\mathrm{CH}_{2}\right), 28.9\left(\mathrm{CH}_{2}\right), 28.4(\mathrm{CH})$, $27.2\left(\mathrm{CH}_{3}\right), 24.9\left(2 \mathrm{C}, \mathrm{CH}_{2}\right), 24.6\left(\mathrm{CH}_{3}\right), 21.0$ $\left(\mathrm{CH}_{3}\right), 18.8\left(\mathrm{CH}_{3}\right)$. El-Mass $\mathrm{m} / \mathrm{z}$ : 222 (base), 207, 189, 179, 161, 151, 138, 125, 109, 98, 83, 69, 41. Its physicochemical properties and spectra data of IR, EI-MS, ${ }^{1} \mathrm{H}$ NMR and ${ }^{13} \mathrm{C}$ NMR were fairly accorded with experimental results reported in literatures [18-23]. The purity of PA was $99.3 \%$ as indicated by GC analysis (Figure 1).

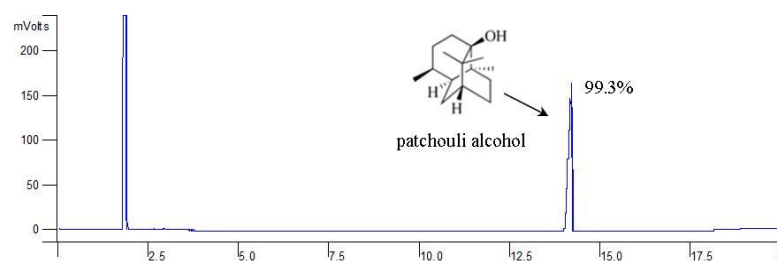

Figure 1: Analytical GC chromatograms of purity determination

\section{Effect of PA on the macrophage phagocytosis}

As displayed in Figure 2, administration of PA at three doses potentiated the indices of phagocytosis $K$ with respect to $P R$ group $(0.0183$ $\pm 0.0083)$ by rapid removal of carbon particles from blood stream. Treatment with $40 \mathrm{mg} / \mathrm{kg}$ and $80 \mathrm{mg} / \mathrm{kg}$ PA had significantly greater carbon clearance ability $(0.0266 \pm 0.0079, p<0.05$; $0.0303 \pm 0.0075, p<0.05)$ than lower dose $(0.0267 \pm 0.0109)$, as indicated by a significant enhancement in phagocytic index.

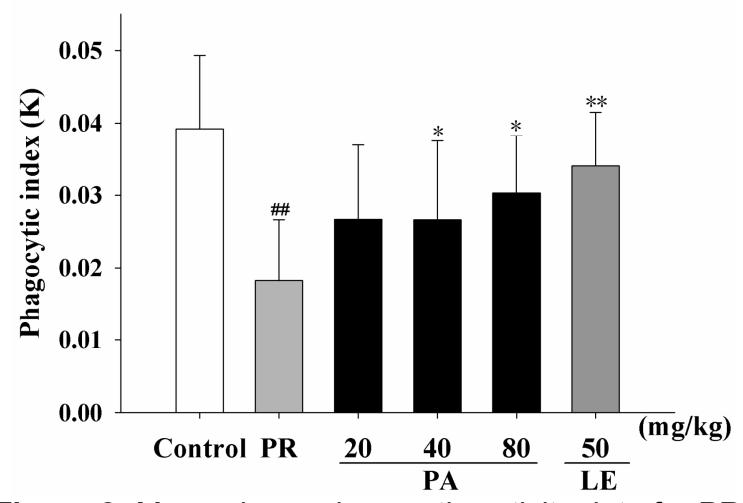

Figure 2: Macrophage phagocytic activity data for PRinduced mice treated with PA. PR group (grey bars), Control group (open column), LE-treated group (50 $\mathrm{mg} / \mathrm{kg} / \mathrm{d}$, dark-grey column) and PA-treated groups $(20,40$, and $80 \mathrm{mg} / \mathrm{kg} / \mathrm{d}$, solid-dark bars). Vertical bars represent standard deviation $(S D, n=10)$. Asterisks designate significant differences: ${ }^{*} p<0.05$ and ${ }^{* *} p<$ 0.01 versus PR group; \#p $<0.05$ and \#\# $<0.01$ versus control group.

Effect of PA on humoral immune responses 
The results are shown in Figures 3A-3B. Administration of PA at three dosages dosedependently boosted the production of circulating serum IgM $(0.077 \pm 0.009,0.080 \pm 0.012$ and $0.081 \pm 0.010)$ and $\lg$ ( $(1.252 \pm 0.112,1.247 \pm$ 0.093 and $1.296 \pm 0.120$ ) respectively, in response to CRBC in PR-induced mice. While $\lg M$ and $\lg$ in $\mathrm{PR}$ group was $0.069 \pm 0.011(p<$ $0.01)$ and $1.180 \pm 0.070(p<0.01)$, respectively. PA at dose of $80 \mathrm{mg} / \mathrm{kg} / \mathrm{d}$ was found to achieve the optimum effect in humoral immunity, resulting in obvious recovery in serum IgG and IgM levels $(p<0.05)$. LE group achieved a more significant increment in IgM $(0.086 \pm 0.012, p<0.01)$ and IgG $(1.322 \pm 0.1054, p<0.05)$ levels.

The effects on mice immune organs (weight divided by body weight) of PA treatment are represented in Figures 4A-4B. Figure 4A displayed that PA administration evoked significant increase $(p<0.05)$ in thymus of mice $(0.35 \pm 0.10,0.35 \pm 0.12$ and $0.37 \pm 0.11$, respectively) in parallel to $\mathrm{PR}$ group $(0.28 \pm$ $0.10)$. Similarly, treatment with PA resulted in increase in spleen $(0.53 \pm 0.13 ; 0.54 \pm 0.14 ; 0.58$ \pm 0.11 , respectively) with respect to PR group $(0.46 \pm 0.15)$ in a dose-related fashion. However, this only became significant $(p<0.05)$ in highdose $(80 \mathrm{mg} / \mathrm{kg})$ group, as shown in Figure 4B.

A

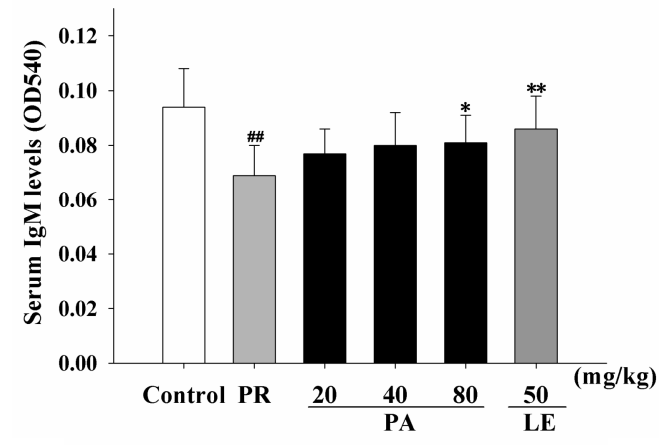

B

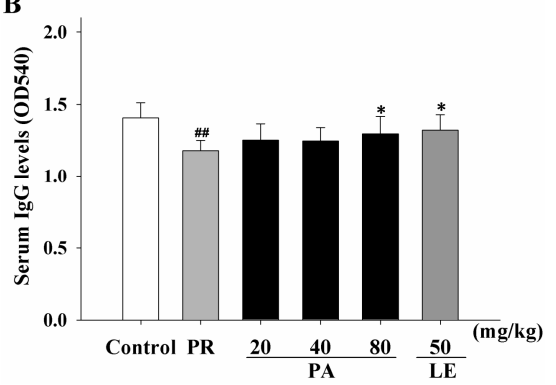

Figure 3: Effect of PA on serum $\operatorname{IgM}(A)$ and $\lg G(B)$ levels in PR-induced mice. PR group (grey bars), Control group (open columns), LE-treated group (50 $\mathrm{mg} / \mathrm{kg} / \mathrm{d}$, dark-grey columns) and PA-treated groups $(20,40$, and $80 \mathrm{mg} / \mathrm{kg} / \mathrm{d}$, solid-dark bars). Vertical bars represent standard deviation $(S D, n=10)$. Asterisks denote significant differences: ${ }^{*} p<0.05$ and ${ }^{* *} p<0.01$ versus PR group; \#p $<0.05$ and \#\#p $<0.01$ versus control group.
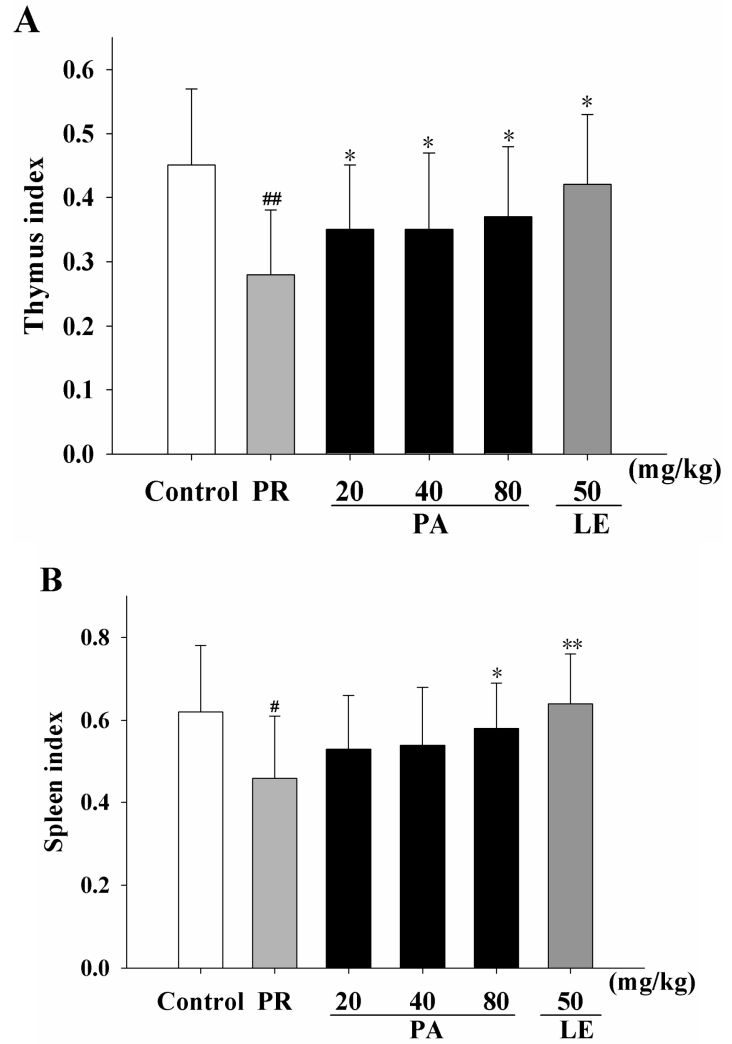

Figure 4: Effect of PA on immune organs-thymus (A) and spleen(B) in PR-induced mice. The results are expressed as the organ indexes using the formula: weight of spleen/thymus (mg)/body weight $(\mathrm{g})$. PR group (grey bars), Control group (open columns), LEtreated group (50 mg/kg/d, dark-grey columns) and PA-treated groups $(20,40$, and $80 \mathrm{mg} / \mathrm{kg} / \mathrm{d}$, solid-dark bars). Vertical bars represent standard deviation (SD, $\mathrm{n}=10$ ). Asterisks designate significant differences: ${ }^{*} p$ $<0.05$ and ${ }^{* *} p<0.01$ versus PR group; $\# p<0.05$ and $\# \# p<0.01$ versus control group.

\section{DNCB-induced DTH}

The results of the effect of PA on cell-mediated immune response (CMI) through DTH are summarized in Figure 5. Oral administration of $\mathrm{PA}$ at three tested doses displayed suppressive effect $(0.75 \pm 0.45 \mathrm{mg}, 0.98 \pm 0.61 \mathrm{mg}$ and 1.03 $\pm 0.40 \mathrm{mg}$ ) in DNCB-induced DTH response in a dose-dependent manner, in comparison to DNCB-induced group $(1.67 \pm 0.84 \mathrm{mg})$. Treatment with PA at $20 \mathrm{mg} / \mathrm{kg} / \mathrm{d}$ elicited a significant decrease $(p<0.05)$, which was even superior to the positive control PR $(0.83 \pm 0.15$ $\mathrm{mg}, p<0.05)$.

\section{DISCUSSION}

Macrophages are the first line of defense and constitute important participants in the bidirectional interaction between innate and specific immunity. Macrophages are pivotal effector cells of the innate immune system and 
thus play an important role in the defense mechanism against host infection. Phagocytic defects are associated with varied pathological conditions in humans [24]. In view of the vital role performed by macrophages, PA was evaluated for its possible effect on macrophage phagocytic activity. For this, the phagocytic index was measured with colloidal carbon ink as the granular foreign body. In the present work, administration of PA caused a significant, doserelated potentiation of macrophage phagocytic activity. The results suggest that PA exhibits stimulatory effect on the cells of mononuclear phagocytic system. PA treatment stimulate the reticulo-endothelial system (RES), thus improving the effect of phagocytosis by mononuclear-macrophage and immune function in mice.

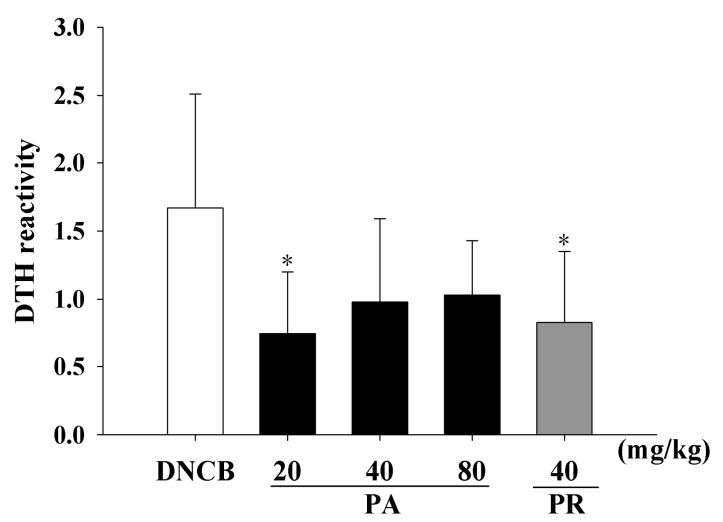

Figure 5: Effect of PA treatment on cell-mediated immune response by DTH in DNCB-induced mice. DNCB-induced group (open bars), PR-administrated groups (40 mg/kg/d, dark-grey columns) and PAtreated groups $(20,40$, and $80 \mathrm{mg} / \mathrm{kg} / \mathrm{d}$, solid-dark bars). Vertical bars represent standard deviation (SD, $\mathrm{n}=12$ ). Asterisks denote significant differences: ${ }^{*} p<$ 0.05 and ${ }^{* *} p<0.01$ versus DNCB-induced group.

Immune organs of animals are important sites where the immune cells develop, establish and proliferate, thus reflecting the general immune function. Immune organs consisted of central immune organs (thymus, etc) and peripheral immune organs (spleen, etc.). Thymus is devoted to thymocyte differentiation and maturation, and is therefore the primary source of circulating $T$ lymphocytes [25]. The spleen makes disease-fighting components of the immune system (including antibodies and lymphocytes) [25]. Besides, spleen serves as a reservoir for blood and filters or purifies the blood and lymphatic fluid that flows through it. When the spleen is damaged or removed, the individual is more susceptible to infections [26]. The preliminary indicators of immune organs are commonly presented as the immune organ index. The significant increase in relative weight of thymus and spleen suggest that PA may be inhibitory to PR-induced atropy of these immune organs.

IgG and $\operatorname{lgM}$ are the major immunoglobulins which involved in complement activation, opsonization, and neutralization of toxins [27]. The estimation of serum immunoglobulin level is a direct measure of humoral immunity and is an index of the functional status of developmental phases of the humoral immune response viz antigen recognition, activation, and expression [28]. In the present investigation, PA treatment elevated the circulating serum $\lg$ and $\lg M$ levels in immune-suppressed mice, thus playing a positive role in augmenting the humoral immune.

DTH reaction, which directly correlates with the competence of CMl function, is an autoimmune response mediated by $\mathrm{T}$ cells and monocytes/macrophages. DTH reaction requires the specific recognition of a given antigen by activated $\mathrm{T}$ lymphocytes, which subsequently proliferate and release cytokines and lymphocytes. Exposure of PA produced a significant decrement in DTH reaction in mice, indicating the suppressive effect of PA on $\mathrm{T}$ lymphocytes and accessory cell types required for the expression of DTH reaction. These results suggest that PA administration produces less inflammatory response. A recent finding from our laboratory showed that PA was an important antiinflammatory constituent of $P$. cablin $[10,13]$. PA treatment reversed the increased mRNA expression of TNF- $\alpha$, IL-1 $\beta$, inducible nitric oxide synthase (iNOS) and cyclooxygenase (COX)-2 caused by lipopolysaccharide in RAW 264.7 cells and in carrageenan-treated rats $[10,13]$. The present observation demonstrated that PA, besides having a direct effect as an antiinflammatory agent, might also reduce inflammation indirectly through the inhibition of cell-mediated immune response.

The results in general demonstrate an improvement in innate immunity in mice administered PA, as evidenced by significant elevation in phagocytic capability, immune organ index, serum IgG and IgM levels, and reduced DTH. Herewith, findings from the present investigation confirms that PA has appreciable immunomodulatory property, which specifically acted by activating the function of the mononuclear phagocytic system, augmenting humoral immune response, and suppressing cellular immune response.

To the best of our knowledge, this is the first report on the in vivo immunomodulatory activity of PA, via different immune response assays in mice. Based on the outcomes from laboratory 
studies, combined with its traditional application, it is reasonable to hypothesize that PA may account at least in part, for the use of $P$. cablin in folk medicine to treat various immunological diseases.

\section{CONCLUSION}

The overall observations of the present work suggested PA held appreciable immunomodulatory property which acted by activating the function of the mononuclear phagocytic system, augmenting humoral immune response, while suppressing the cellular immune. The current study has thus provided baseline information on the potential use of PA as a promising immunomodulatory agent.

\section{ACKNOWLEDGEMENT}

This work was supported by Guangdong International Cooperation Projects (No. 2012B050300002); National Natural Science Foundation of China (No. 81173534); Science and Technology Planning Project of Guangdong (No. 2012A080202002); Science and Technological Program of Dongguan's Higher Education, Science and Research, and Health Care Institutions (No. 2012105102009).

The authors, JBL and DWW, equally contributed to this work.

\section{REFERENCES}

1. Surendra SA, Gokul ST. Bioactivity guided isolation and characterization of the phytoconstituents from the Tridax procumbens. Revista Brasileira de Farmacognosia. Brazilian Journal of Pharmacognosy 2011; 21(1): 58-62.

2. Biswadev B, Roychowdhury S, Ghosh S, Sengupta M. Hepatoprotective and immunomodulatory properties of Tinospora cordifolia in $\mathrm{CCl}_{4}$ intoxicated mature albino rats. J Toxicol Sci 2002; 27(3): 139-146.

3. Bani S, Kaul A, Khan B, Ahmad SF, Suri KA, Satti NK, Amin M, Qazi GN. Immunosuppressive properties of an ethyl acetate fraction from Euphorbia royleana. $J$ Ethnopharmacol 2005; 99(2): 185-192.

4. Ghule BV, Murugananthan G, Nakhat PD, Yeole PG. Immunostimulant effects of Capparis zeylanica Linn. Leaves. J Ethnopharmacol 2006; 108(2): 311-315.

5. Bhat BA, Dhar KL, Pun SC, Quirishi MA, Khajuria A, Gupta A, Qazi GN. Isolation, characterization and biological evaluation of datura lactones as potential immunomodulators. Bioorg Med Chem 2005; 13(24): 6672-6677.

6. Srisilam $K$, Sumalatha $D V$, Thilagam E, Veeresham $C$. Immunomodulators from higher plants, Indian J Nat Prod, 2000; 20, 3-15.

7. Qi SS, Hu LP, Chen WN, Sun HB, Ma XD Immunological regulation effects of essential oil in leaves of Cablin herbal on mice. Chin Arch Tradit Chin Med 2009, 27(4): 774-776.
8. Suo J, Xian YF, Huang XD, Hou SZ, Chen JN, Ye MR, Su $Z R$. A pharmacological study on the anti-allergy effects of refined Huodan recipe. Chin J Exp Tradit Med Formul 2007; 13(9): 47-49.

9. Hybertson BM. Solubility of the sesquiterpene alcohol patchoulol in supercritical carbon dioxide. J Chem Eng Data 2007; 52(1): 235-238.

10. Li YC, Xian YF, IP SP, Su ZR, Su JY, He JJ, Xie QF, Lai $X P$, Lin ZX. Anti-inflammatory activity of patchouli alcohol isolated from Pogostemonis Herba in animal models. Fitoterapia 2011; 82(8): 1295-1301.

11. Yang Y, Kinoshita K, Koyama K, Takahashi K, Tai T, Nunoura Y, Watanabe K. Anti-emetic principles of Pogostemon cablin (Blanco) Benth. Phytomedicine 1999; 6(2): 89-93.

12. Li YC, Peng SZ, Chen HM, Zhang FX, Xu PP, Xie JH, He $J J$, Chen JN, Lai XP, Su ZR. Oral administration of patchouli alcohol isolated from Pogostemonis Herba augments protection against influenzaviral infection in mice. Int Immunopharmacol 2012; 12(1): 294-301.

13. Xian YF, Li YC, Ip SP, Lin ZX, Lai XP, Su ZR. Antiinflammatory effect of patchouli alcohol isolated from Pogostemonis Herba in LPS-stimulated RAW 264.7 macrophages. Exp Ther Med 2011; 2: 545-550.

14. Chinese Association For Laboratory Animal Sciences. Guidelines to Good Practice in Laboratory Animals Feeding and Management. 2009.

15. Hudson L, Hay FC. Practical immunology. 2nd ed. London: Blackwell; 1980. pp. 73-92.

16. Duan BW, Li Y, Liu X, Yang YJ. Effect of polysaccharides immunologic function of immunosuppression mice. Chin J Chin Mater Med 2010; 35(11): 1466-1469.

17. Ma SP, Qu R, Hang BQ. Immunologic inhibition and antiallergic action of Cryptotympana atrata Fabricius. Chin J Chin Mater Med 1989; 14(8): 490-493.

18. Büchi G, MacLeod WD. Synthesis of patchouli alcohol. J Am Chem Soc 1962; 84(16): 3205-3206.

19. Büchi G, MacLeod WD, Padilla OJ. Terpenes. XIX. Synthesis of patchouli alcohol. J Am Chem Soc 1964; 86(20): 4438-4444.

20. Kaliappan KP, Subba Rao GSR. Synthesis Based on Cyclohexadienes: Part 22. Formal Syntheses of Norpatchoulenol and Patchouli Alcohol, J Chem Soc, Perkin Trans. 1997; (9): 1385-1389.

21. Naf $F$, Deconant $R$, Giersch $W$, Ohloff $G A$. Stereocontrolled Access to ( \pm )-, (-)-, and (+)-Patchouli Alcohol. Helv Chim Acta 1981; 64(5) :1387-1397.

22. Srikrishna A, Satyanarayana G. An enantiospecific total synthesis of (-)-patchouli alcohol. Tetrahedron: Asymmetry 2005; 16(24): 3992-3997.

23. Nishiya K, Tsyjiyama $T$, Kimura $T$, Takeya $K$, Itokawa $H$, litaka Y. Sesquiterpenoids from Valeriana fauriei. Phytochemistry 1995; 39(3) 713-714.

24. White CJ, Gallin JI. Phagocyte defects. Clin Immunol Immunopathol 1986; 40(1): 50-61.

25. Jiang MH, Zhu L, Jiang JG. Immunoregulatory actions of polysaccharides from Chinese herbal medicine. Expert Opin Ther Targets 2010; 14(12): 1367-1402.

26. Tripathi AS, Chitra V, Sheikh NW, Mohale DS, Dewani AP. Immunomodulatory Activity of the Methanol Extract of Amorphophallus campanulatus (Araceae) Tuber. Trop J Pharm Res 2010; 9(5): 451-454.

27. Silkworth JB, Loose $L D$. Assessment of environmental contaminant-induced lymphocyte dysfunction. Environ Health Persp 1981; 39: 105-128.

28. Benacerraf B. Hypothesis to relate the specificity of $T$ lymphocyte and the activity of I region specific Ir genes in macrophages and B lymphocytes. J Immunol 1978; 120: 1809-1812. 